University of Nebraska - Lincoln

DigitalCommons@University of Nebraska - Lincoln

\title{
Continuous Dryland Cropping in the Great Plains: What Are the Limits?
}

Drew J. Lyon

University of Nebraska-Lincoln, drew.lyon@wsu.edu

Gary Peterson

University of Nebraska-Lincoln

Follow this and additional works at: https://digitalcommons.unl.edu/panhandleresext

Part of the Agriculture Commons

Lyon, Drew J. and Peterson, Gary, "Continuous Dryland Cropping in the Great Plains: What Are the Limits?" (2005). Panhandle Research and Extension Center. 10.

https://digitalcommons.unl.edu/panhandleresext/10

This Article is brought to you for free and open access by the Agricultural Research Division of IANR at DigitalCommons@University of Nebraska - Lincoln. It has been accepted for inclusion in Panhandle Research and Extension Center by an authorized administrator of DigitalCommons@University of Nebraska - Lincoln. 


\title{
Agronomy Journal
}

Volume 97

March-April 2005

Number 2

\section{SYMPOSIUM PAPERS}

\section{Continuous Dryland Cropping in the Great Plains: What Are the Limits?}

\author{
Drew J. Lyon* and Gary A. Peterson
}

$T$ HE FOLLOWING six papers were presented at the symposium entitled "Continuous Dryland Cropping in the Great Plains: What Are the Limits?" held during the 2003 ASA-CSSA-SSSA annual meetings in Denver, CO. The symposium was organized by Division S-6 and cosponsored by Divisions A-8 and C-3.

The Great Plains is a vast interior region of North America with a temperate, semiarid climate that is subject to wide fluctuations in precipitation, temperature, and wind speed. The most common cropping system in the region is wheat (Triticum aestivum L.)-fallow where one crop is harvested every 2 yr. Summer fallow, the practice of controlling all plant growth during the noncrop season, is commonly used in this region to stabilize wheat production. It has been shown, however, that summer fallow results in soil degradation, limits farm productivity and profitability, and stores soil water inefficiently.

The consensus of a 1994 ASA-CSSA-SSSA symposium on cropping systems in the Great Plains was that more intensive cropping systems were not only feasible, but that adoption was essential for the long-term sustainability of agriculture in the region (Peterson, 1996). Peterson et al. (1996) made the case that intensified cropping systems improved precipitation use efficiency in dryland systems and that maximum system efficiency depended on selection of the most efficient plants for a given region. Integrated production systems that include both crop and livestock components were discussed by Krall and Schuman (1996). System benefits included the potential to improve soil quality and pest control as well as added economic diversity; however, tradition, lack of managerial experience, and lack of necessary infrastructure were identified as constraints to adoption of

D.J. Lyon, Panhandle Res. and Ext. Cent., 4502 Ave. I, Scottsbluff, NE 69361-4939; and G.A. Peterson, Soil and Crop Sci. Dep., Colorado State Univ., Ft. Collins, CO 80523-1170. Received 3 Mar. 2004. *Corresponding author (DLYON1@unl.edu).

Published in Agron. J. 97:347-348 (2005).

(C) American Society of Agronomy

677 S. Segoe Rd., Madison, WI 53711 USA integrated systems. Westfall et al. (1996) emphasized the importance of $\mathrm{N}$ management in more intensive systems where the yield loss resulting from underfertilization is greater than in winter wheat-fallow systems. Integrated pest management concepts, as they relate to dryland cropping systems, were presented by Holtzer et al. (1996). Lyon et al. (1996) discussed the important role of herbicides in dryland weed control systems and the need to maintain their usefulness through the implementation of integrated weed control practices. More intensified systems with less tillage were found to have greater production costs than winter wheat-fallow, but they also had increased net return and reduced financial risk (Dhuyvetter et al., 1996).

Since the 1994 symposium, many growers in the Great Plains have adopted cropping systems that involve less frequent summer fallow, but summer fallow remains an integral part of most dryland cropping systems in the region. Increasing numbers of growers and researchers are asking the question: How intensive can we farm in the Great Plains? Can the use of summer fallow be eliminated? What are the limits to continuous dryland cropping in the Great Plains?

This symposium was designed to follow in the footsteps of the 1994 symposium and to challenge ourselves to determine the practical limits to cropping intensity in the Great Plains. The symposium papers cover the key issues that must be addressed if we are to eliminate the practice of summer fallow. These include the efficient use of water, crop sequencing, pest management concerns and options, the potential need to alter $\mathrm{N}$ fertility recommendations (currently based on work conducted in systems involving summer fallow), effects on $\mathrm{C}$ storage and soil quality, and the potential for using crop simulation modeling to help ascertain the risks of farming without summer fallow.

A recurring theme coming out of the symposium was the need to better understand and deal with variability (risk), which is an inherent part of any cropping enterprise conducted within the highly variable environment of the U.S. Great Plains. Indeed, the practice of summer 
fallow was developed and introduced into the region in the early twentieth century, in large measure, to stabilize production and income levels. The elimination of summer fallow is likely to increase variability in crop response to management. Although this will make it more difficult for researchers to identify superior management practices, particularly over a short time horizon, variability can be exploited if it is understood. Strategies must be developed to help growers manage risk without the use of summer fallow if we are to sustain agricultural production in the Great Plains.

\section{REFERENCES}

Dhuyvetter, K.C., C.R. Thompson, C.A. Norwood, and D.A. Halvorson. 1996. Economics of dryland cropping systems in the Great Plains: A review. J. Prod. Agric. 9:216-222.
Holtzer, T.O., R.L. Anderson, M.P. McMullen, and F.B. Peairs. 1996. Integrated pest management of insects, plant pathogens, and weeds in dryland cropping systems of the Great Plains. J. Prod. Agric. 9:200-208.

Krall, J.M., and G.E. Schuman. 1996. Integrated dryland crop and livestock production systems on the Great Plains: Extent and outlook. J. Prod. Agric. 9:187-191.

Lyon, D.J., S.D. Miller, and G.A. Wicks. 1996. The future of herbicides in weed control systems of the Great Plains. J. Prod. Agric. 9: 209-215.

Peterson, G.A. 1996. Cropping systems in the Great Plains. J. Prod. Agric. 9:179.

Peterson, G.A., A.J. Schlegel, D.L. Tanaka, and O.R. Jones. 1996. Precipitation use efficiency as affected by cropping and tillage system. J. Prod. Agric. 9:180-186.

Westfall, D.G., J.L. Havlin, G.W. Hergert, and W.R. Raun. 1996. Nitrogen management in dryland cropping systems. J. Prod. Agric. 9:192-199. 